\title{
Seqüências de uma Sociologia Política Brasileira*
}

\author{
André Botelho
}

“O que eu esperaria para o Brasil era uma atividade complementar desse belo labor dos nossos filósofos sociais. Era, aos estudiosos com gosto da investigação, um apelo mais freqüente aos métodos científicos de pesquisas, uma preocupação mais sistemática pelos problemas objetivos".

(Francisco José de Oliveira Vianna, 1991)

\begin{abstract}
“De modo geral, a ligação entre o conhecimento científico e a filosofia que o sustenta não conta para o especialista que perdeu essa memória nos labirintos do treinamento". (Maria Sylvia de Carvalho Franco, 1970)
\end{abstract}

\begin{abstract}
$\mathrm{O}$ baralhamento entre público e privado enquanto ordens sociais e princípios distintos de orientação das condutas como uma marca da cultura política, da sociedade e do Estado formados no Brasil desde a colonização portuguesa constitui uma das construções intelectuais mais tenazes do seu pensamento social. E também uma das principais linhas que, com continuidades e descontinuidades, o liga à produção das ciências sociais posterior à institucionalização, particularmente na
\end{abstract}

*A realização deste estudo contou com o apoio da Fundação Universitária José Bonifácio.

DADOS - Revista de Ciências Sociais, Rio de Janeiro, Vol. 50, no 1, 2007, pp. 49 a 82. 
vertente voltada para a investigação das bases sociais da vida política nacional, suas raízes rurais e influências duradouras sobre o urbano então emergente ${ }^{1}$. Populações Meridionais do Brasil (1920) de Oliveira Vianna é paradigmático a esse respeito, na medida em que se mostrou capaz de interpelar, no plano cognitivo, diferentes trabalhos posteriores, não obstante muitos deles divergirem radicalmente do seu sentido político original - interpelação que pode ser identificada tanto no plano teórico-metodológico, quanto no substantivo. No primeiro, porque, traduzindo crítica mais ampla ao status quo da Primeira República sobre a desarticulação entre as instituições liberais "transplantadas" e a realidade "singular" brasileira, o ensaio de estréia de Oliveira Vianna formaliza a tese segundo a qual na vida social se encontrariam os fundamentos e a dinâmica das instituições políticas. Daí, ao lado da convicção que expressa sobre a necessidade de um conhecimento "objetivo" e "científico" do social (Bastos, 1993; Bresciani, 2005), sua consistente, ainda que controversa, defesa da precedência lógica da sociologia sobre a política ou do homo sociologicus sobre o homo politicus (Werneck Vianna, 1993:373; Brandão, 2001). E, substantivamente, porque sua tese sobre a particularidade da relação entre público e privado, segundo a qual a hipertrofia da ordem privada e seu predomínio histórico sobre a ordem pública constituiriam não apenas elementos centrais da formação rural da sociedade brasileira, como também representariam impasses tenazes para sua modernização, conheceu desdobramentos distintos na produção intelectual posterior.

É justamente da recepção de idéias de Oliveira Vianna na produção das ciências sociais institucionalizadas como cursos universitários desde a década de 1930, ou mais precisamente do seu papel na formação do "contexto intelectual" ou "léxico" de uma das suas vertentes, que trata o presente artigo ${ }^{2}$. Populações Meridionais do Brasil é tomado, nesse sentido, como ponto de partida da formação de uma agenda de pesquisas que, mais do que simplesmente relacionar política e sociedade, ambiciona especificar as bases sociais e a dinâmica social da política originadas na formação rural do Brasil, e que justamente por isso é aqui nomeada de "sociologia política" ${ }^{3}$. Não obstante recente discussão sobre o papel de Oliveira Vianna como "precursor" dessa vertente disciplinar (Silva, 2002), uma vez que voltada para a questão da formação de uma "ideologia autoritária" de Estado, a sua possível influência propriamente cognitiva nas ciências sociais, embora há muito assinalada (Santos, 1978), permanecia sem desdobramentos analíticos mais consistentes ${ }^{4}$. Neste artigo, procurar-se-á mostrar, em primeiro lugar, que Coronelis- 
mo, Enxada e Voto, de 1949, de Victor Nunes Leal; "Política, Ascensão Social e Liderança num Povoado Baiano", de 1962, e O Mandonismo Local na Vida Política Brasileira e Outros Ensaios, de 1976, de Maria Isaura Pereira de Queiroz (este último reunindo trabalhos produzidos desde a década de 1950); e Homens Livres na Ordem Escravocrata, de 1964, de Maria Sylvia de Carvalho Franco, são paradigmáticos a esse respeito; e, em segundo lugar, que, consideradas em conjunto, de uma perspectiva analítica, estas pesquisas forjam no diálogo empreendido com o ensaio de Oliveira Vianna uma vertente da sociologia política brasileira.

Para efeitos analíticos, destaca-se uma das teses principais de Populações Meridionais do Brasil nem sempre considerada em primeiro plano, ainda que diferentes aspectos correlatos a ela já tenham sido tratados ${ }^{5}$. Refere-se à configuração particular que a formação da sociedade teria engendrado à dominação política no Brasil. Esta seria marcada não diretamente pelo conflito de classes enraizado na organização social da produção, mas antes, e na ausência dessa forma específica de "solidariedade social" entre nós, pelo conflito entre público e privado ${ }^{6}$. Em outras palavras, para Oliveira Vianna, a chave para a compreensão sociológica da dominação política estaria no conflito entre público e privado enquanto ordens sociais distintas, concorrentes, regidas por princípios próprios de orientação das condutas apenas indiretamente associados às relações econômicas e cujo baralhamento histórico teria concorrido ainda para conferir um caráter direto, pessoalizado e violento às relações políticas. O fundamento dessa configuração particular da dominação política no Brasil, reiterado ao longo da formação da sociedade, estaria em uma ambigüidade histórica que nos singularizaria: os mesmos processos que tornavam as relações de solidariedade entre a "aristocracia senhorial" e a "plebe rural" frágeis, frouxas, instáveis, desnecessárias no plano econômico (e secundariamente militar ou religioso) concorreriam para fortalecê-las para efeitos políticos.

A origem dessa ambigüidade da solidariedade social à brasileira, cabendo ressaltar que, no ensaio, Oliveira Vianna emprega a noção ora em um sentido normativo (capacidade de livre associação), ora em um sentido mais descritivo (formas de identificação e interação intersubjetivas), estaria nas formas sociais assumidas pela propriedade fundiária no Brasil desde a colonização portuguesa. Sua desmedida amplitude, dispersão pelo território e feição autonômica teriam moldado o latifúndio como centro de gravitação da sociedade colonial, cuja força centrípeta teria concorrido, de um lado, para a simplificação da estru- 
tura social global da sociedade, dificultando a dinamização do comércio, da indústria, dos núcleos urbanos e seus atores sociais característicos (especialmente uma classe média autônoma e independente, base social crucial para o vigor associativo das sociedades anglo-saxônicas tomadas como contraponto à formação social brasileira); e, de outro, para definir, ao lado da escravidão, da amenidade dos climas tropicais e da abundância de terras privadamente controladas, mas não diretamente incorporadas à produção agrário-exportadora assegurada pela mão-de-obra cativa, as mesmas qualidades das relações de solidariedade social internamente aos domínios rurais.

Esses mesmos processos teriam engendrado a organização dos diferentes grupos sociais rurais formalmente livres sob a liderança do grande proprietário no "clã rural", não apenas unidade da sociedade que se vinha formando desde a colônia, mas, por isso mesmo, a "força motriz" de toda a nossa história política e "causa primeira da sua dinâmica e evolução" (Vianna, 1973:139). Sem ter quem lhes contestasse efetivamente o poder, os clãs rurais abriam espaços no incipiente domínio público da sociedade brasileira para formular e promover programas que expressassem seus interesses particulares. Mecanismo designado de "anarquia branca" e que expressa a capacidade de apropriação privada das instituições públicas que acaba por distorcer e lhe redefinir o sentido, demonstrado no ensaio em relação à justiça, ao recrutamento militar e às corporações municipais. Nessas condições, a fragilidade e a parcialidade a que as instituições públicas estavam sujeitas favoreciam a que os diferentes grupos sociais subalternos se refugiassem sob o "poder tutelar" dos clãs rurais. E, justamente por isso, argumenta Oliveira Vianna, aquilo que

"[...] nem o meio físico, nem o meio econômico podem criar de uma forma estável, à semelhança do que acontece no Ocidente, cria-o a patronagem política, a solidariedade entre as classes inferiores e a nobreza rural. Vimo-las disjuntas; vemo-las agora dependentes e conexas" (idem:148, ênfases no original).

São estes, em linhas gerais, os fundamentos sociais da dominação política no Brasil para Oliveira Vianna, verdadeiras "leis" regentes da formação e da organização da sociedade brasileira (idem:241) que redundaram na dificuldade ou mesmo impedimento de criação de instâncias de livre associação entre os indivíduos que visassem aos interesses públicos. Noutras palavras, o papel desempenhado pelo latifúndio auto-suficiente na formação da sociedade brasileira teria levado a uma 
restrição das práticas associativas ao âmbito privado, doméstico e familiar, constrangendo decisivamente a constituição de ações coletivas em torno de interesses comuns mais vastos, o que Oliveira Vianna chamou de "insolidarismo" social (idem:155) ${ }^{7}$. De tal modo que nação, classes, partidos políticos, corporações, sindicatos e outras formas sociais de associação seriam "entre nós, ou meras entidades artificiais e exógenas, ou simples aspirações doutrinárias, sem realidade efetiva na psicologia subconsciente do povo" (idem:242). Seria, pois, em face da ameaça de fragmentação da sociedade decorrente do próprio processo de formação social que se faria urgente reorganizar, fortalecer e centralizar o Estado, único ator considerado capaz de enfraquecer politicamente as oligarquias agrárias e sua ação corruptora das liberdades públicas e, desse modo, corrigindo os defeitos da nossa formação social, dar novos nexos institucionais à sociedade. Trata-se sem dúvida de proposição não apenas normativa, como teleológica, como se a construção desse Estado não fosse mais do que uma etapa necessária em uma seqüência de desenvolvimento predeterminada pelos impasses sociais produzidos na formação da sociedade brasileira.

Abordando, por sua vez, fenômenos como "coronelismo", "mandonismo" e "dominação pessoal" de perspectivas históricas e empíricas mais definidas, as pesquisas de Victor Nunes Leal, Maria Isaura Pereira de Queiroz e Maria Sylvia de Carvalho Franco retomam a problemática da dominação política proposta por Oliveira Vianna. A começar justamente pelo fato de que voltam ao passado remoto ou recente da sociedade brasileira para evidenciar aqueles fenômenos de dominação política que, já assinalados em Populações Meridionais do Brasil, pareciam persistentes na passagem do rural ao urbano. Além disso, as pesquisas destacadas procuram tanto relacionar aquisição, distribuição, organização e exercício de poder político à estrutura social no plano teórico-metodológico, ainda que de uma perspectiva empírica própria da sociologia como especialidade, quanto situar suas análises a partir do conflito entre privado e público, e apenas indiretamente às relações desenvolvidas no mundo da produção, compartilhando ainda da tese de que o baralhamento entre aqueles diferentes princípios de coordenação social conformaria a peculiaridade da dominação política no Brasil. Também como no ensaio de Oliveira Vianna, esta é vista nas pesquisas integrando um "sistema de reciprocidades" assimétricas que envolveria bens materiais e imateriais, controle de cargos públicos, votos, recursos financeiros, prestígio, reconhecimento de autoridade le- 
gal ou não etc. com base em relações diretas, pessoalizadas e violentas engendradas entre os diferentes grupos sociais 8 .

Todavia, com sentido crítico, aporte teórico, ênfase empírica e resultados também bastante diferenciados, as pesquisas de Leal, Queiroz e Franco recusam a visão normativa e teleológica de Oliveira Vianna, o que lhes permite desestabilizar progressivamente a própria oposição disjuntiva com que a relação público/ privado é proposta na sua interpretação do Brasil. Levando às últimas conseqüências a tese dos fundamentos sociais da ação, das interações e das instituições políticas, e tomando para si a tarefa de investigar no que consistia exatamente o baralhamento entre público e privado, acabam por demonstrar a impropriedade de uma concepção dualista sobre esses diferentes princípios de coordenação social no Brasil. Como a recepção de uma mesma idéia não desempenha um objetivo único em diferentes análises, cumpre observar, por outro lado, a diversidade de sentidos assumidos pela tese de Oliveira Vianna sobre as relações entre público e privado na origem social da dominação política brasileira de uma pesquisa para outra. Isto nos remete, do ponto de vista teórico, para as diferentes concepções de sociedade que cada uma delas assume e, ao mesmo tempo, procura conferir verossimilhança com os resultados obtidos no estudo da dominação política. Com o objetivo de perscrutar os ganhos teóricos heurísticos produzidos pela vertente da sociologia política aqui abordada, o estudo explora as diferentes formulações de cada um dos trabalhos sobre a relação entre "ação" e "estrutura" presente em suas respectivas concepções de sociedade, dualidade em grande medida constitutiva da teoria sociológica em geral (Domingues, 2004). E a visão renovada das bases e da dinâmica sociais da vida política a que chegam as pesquisas da sociologia institucionalizada em diálogo com a tradição do pensamento social encontra-se, como veremos, cronicamente associada às novas e diferentes variáveis analíticas sobre a própria sociedade que cada uma introduz e que lhes permite alcançar resultados distintos.

A ausência de provas textuais convencionais contundentes, já que as pesquisas de Queiroz e de Franco sequer citam Oliveira Vianna e a de Nunes Leal não lhe concede o lugar que estamos destacando, não é razão suficiente para desestimular a recomposição analítica de possíveis afinidades entre os seus trabalhos. Afinidades, aliás, já assinaladas no que diz respeito a Oliveira Vianna, Leal e Queiroz (Carvalho, 1993; 1998), e às sociólogas da Universidade de São Paulo - USP e o ensaísta 
de Saquarema (Brandão, 2005). Lembro que razões plausíveis para o silêncio sistemático que se abateu especificamente sobre obra do consultor jurídico do Ministério do Trabalho e um dos principais ideólogos da política sindical e social corporativa do Estado Novo já foram persuasivamente apontadas, sobretudo tendo em vista que os principais resultados, em termos de produção de conhecimento, das ciências sociais institucionalizadas começaram a surgir justamente em torno da década de 1950 no contexto de redemocratização do Brasil (Carvalho, 1993). Ademais, como todo silêncio é eloqüente, deve-se observar que não apenas os limites do "vocabulário normativo" disponível em qualquer época contribuem "para determinar as vias pelas quais certas questões em particular virão a ser identificadas e discutidas"; como também que, no campo do conhecimento, os autores não se limitam a endossar ou contestar explicitamente as idéias uns dos outros, mas também se dedicam a ignorá-las de forma polêmica (Skinner, 1999:10 e ss.).

A pesquisa do perfil cognitivo da sociologia política brasileira não supõe, contudo, que as afinidades identificadas entre os diferentes trabalhos que a compõem impliquem qualquer filiação em termos ideológicos; tampouco esgotem a questão das matrizes intelectuais que os alimentam, seja no campo do pensamento social brasileiro seja no da teoria sociológica ${ }^{9}$, ainda que valha a pena explorar a hipótese mais ampla segundo a qual o pensamento social brasileiro tem representado um "afiado instrumento de regulação de nosso mercado interno de idéias em suas trocas com o mercado mundial" (Brandão, 2005:233). Isso não implica, igualmente, supor que as pesquisas de Leal, Queiroz ou Franco tenham sido formuladas meramente como uma resposta à interpretação do Brasil de Oliveira Vianna, ainda que esta tenha integrado o debate intelectual e desempenhado papéis cruciais como cultura política no relacionamento entre Estado e sociedade no Brasil ao longo do século XX.

\section{PÚBLICO E PRIVADO COMO "SISTEMA"}

Coronelismo, Enxada e Voto. O Município e o Regime Representativo no Brasil, de 1949, formulado originalmente no ano anterior como tese para provimento da cadeira de Política da Faculdade Nacional de Filosofia da Universidade do Brasil, representa um passo fundamental na desestabilização da antinomia público $/ \operatorname{privado}^{10}$. Seu tema central são as relações entre poder local e poder nacional que se desenvolvem historicamente, no Brasil, em um tipo de dialética entre a falta de "autono- 
mia legal" dos municípios e a ampla "autonomia extralegal" de que os chefes políticos municipais governistas sempre gozaram (Leal, 1997:71). Embora destaque nessas relações, a questão da liderança política do "coronel" e da sua influência nos municípios rurais, advertindo, contudo, que nem sempre os chefes políticos locais são "autênticos" coronéis (idem:41), a ênfase analítica de Leal incide sobre o sistema político. O coronel na verdade seria a parte mais aparente de um fenômeno mais complexo, apenas uma parte do "coronelismo" e sequer a mais forte. O coronel, como o autor esclareceu em texto posterior, "entrou na análise por ser parte do sistema; mas o que mais me preocupava era o sistema, a estrutura e maneira pelas quais as relações de poder se desenvolviam a partir do município, mostrando que na Primeira República a figura do senhor absoluto já desaparecera por completo" (idem:36).

Para chegar à compreensão sistemática da problemática da dominação política no Brasil para além da sua aparência, os materiais de pesquisa selecionados e a maneira como foram tratados são fundamentais. Nunes Leal mobiliza um conjunto diversificado de materiais, entre interpretações de outros autores, e, sobretudo, recenseamentos, constituições e legislações das mais diferentes ordens, tais como sobre a qualificação dos eleitores e representantes políticos, sobre a distribuição de tributos e impostos e as relacionadas à disposição do poder judiciário e do poder político. Ao percorrer esse material, empregando recursos comparativos entre períodos históricos, sobretudo, entre a colônia e a Primeira República, este último o período específico em foco no seu trabalho, Leal tem dois objetivos principais relacionados. De um lado, estabelecer as interconexões significativas do processo político brasileiro a partir do município e, de outro, avaliar em que medida, através do tempo, as legislações favoreceram ou desfavoreceram os municípios. Isto porque, na lógica de Coronelismo, Enxada e Voto, quanto maior a descentralização e o aumento do poder legislativo, judiciário e tributário dos municípios, maiores seriam as condições para o combate ao coronelismo e sua estrutura clientelística (idem:70-74), no que, então, se coloca em posição frontalmente oposta à de Oliveira Vianna e sua defesa da centralização e fortalecimento do Estado como condição crucial de enfraquecimento político do poder local dos grandes proprietários fundiários.

Com base na análise daqueles materiais de pesquisa, Nunes Leal chega a duas constatações fundamentais que, pondo à mostra a complexida- 
de do fenômeno político e seus fundamentos sociais, contrariavam, em grande medida, as idéias até então mais difundidas a respeito do coronelismo. Em primeiro lugar, que este se fundava em uma ampla rede de relações e pactos políticos em diferentes instâncias, do município à esfera federal, passando centralmente pela estadual, toda essa rede perpassada por favores e compromissos recíprocos entre as suas diferentes partes constitutivas. Neste "sistema de reciprocidade", como nomeia, entraria tanto o prestígio próprio dos coronéis, cujas raízes sociais estão na estrutura agrária do país, quanto o "de empréstimo que o poder público lhes outorga", ambos "mutuamente dependentes" e funcionando "ao mesmo tempo como determinantes e determinados" (idem:64).

Ao lado dessa caracterização como "sistema de reciprocidade", já assinalada por Oliveira Vianna no que diz respeito às relações entre o "chefe de clã" e sua "clientela" (Vianna, 1973:148-149), a segunda constatação da análise de Nunes Leal é que o coronelismo consistiria fundamentalmente em uma superposição de regimes políticos distintos: um regime baseado no poder do coronel e um sistema de representação política com base no voto individual (Leal, 1997:40). Também aqui, por assim dizer, a sensibilidade histórico-sociológica do catedrático de política mostra-se mesmo fundamental, pois soube tirar conseqüências decisivas do fato de que as inovações institucionais da Primeira República liberal-oligárquica, principalmente o regime eleitoral representativo que ampliou consideravelmente o contingente de eleitores em relação ao do Império, não se fizeram em um vazio social, mas essas inovações encontravam, sim, uma sociedade formada e com cujas estruturas e relações sociais, econômicas e políticas foram forçadas inevitavelmente a interagir - interação da qual resulta a dinâmica própria da vida política brasileira do período.

Afinal, de que sociedade se trata? De uma sociedade formada desde a experiência colonial marcada pelo predomínio do poder privado, hipertrofiado e baseado nos grandes domínios rurais, sobre o poder público e, mesmo contemporaneamente à escritura da tese, marcada, para Nunes Leal, por relações de desigualdade social, violência e pobreza decorrentes da estrutura agrária do país. Estrutura explicativa da própria "hegemonia" dos fazendeiros em relação "aos dependentes da sua propriedade, que constituem o seu maço de votos de cabresto" (idem:75, ênfases no original). Todavia, contrariando expectativas correntes, provavelmente baseadas também na vulgarização das idéias de 
Oliveira Vianna, não seria a força ou a pujança do latifúndio que explicaria o coronelismo, mas antes, a sua própria fraqueza e debilidade. $\mathrm{O}$ coronelismo, Leal argumenta, assentava-se em "duas fraquezas: fraqueza do dono de terras, que se ilude com o prestígio do poder, obtido à custa da submissão política; fraqueza desamparada e desiludida dos seres quase sub-humanos que arrastam a existência no trato das suas propriedades" (idem:78).

Nem o poder praticamente incontestável dos grandes senhores rurais do passado permaneceria incólume, nem a ordem pública sempre frágil. Na transição do rural ao urbano, latifúndios decadentes, mas ainda detentores de poder residual suficiente, e inovações institucionais e econômicas promissoras, mas ainda débeis, encontram-se, misturamse e redefinem-se uns em relação aos outros. Trata-se, então, de um fenômeno historicamente circunscrito que se tornou possível em uma conjuntura muito especial marcada, no plano político, pela substituição do centralismo imperial pelo federalismo e pela expansão da base do regime representativo, operadas pela República; no plano econômico, pela decadência dos fazendeiros, cuja manutenção do poder político se tornava cada vez mais dependente do Estado (Carvalho, 1998).

Mesmo mantendo a proposição de Oliveira Vianna de que a inteligibilidade sociológica da dominação política se encontrava nas relações entre público e privado, Coronelismo, Enxada e Voto acaba, nesse sentido, por virar de ponta-cabeça a tese de Populações Meridionais do Brasil. E isso, mesmo lembrando que, em primeiro lugar, Oliveira Vianna tinha relativa clareza daquele processo, o qual discutiu em termos de um "enfraquecimento" indireto e progressivo do poder privado em face da centralização da autoridade pública operada durante o Império (Vianna, 1973:167-262); e, em segundo, que a sua noção de "anarquia branca" (idem:139) se pretendia explicativa do modo como o clã rural estendia a incipiente ordem pública da sociedade brasileira à sombra do seu poder tutelar. Em relação ao primeiro ponto, Nunes Leal afirma peremptoriamente que não se pode "reduzir" o coronelismo "a simples afirmação anormal do poder privado. É também isso, mas não é somente isso" (Leal, 1997:276). Como sistema político ele envolve, fundamentalmente, uma "relação de compromisso entre o poder privado decadente e o poder público fortalecido" (ibidem). Quanto à questão da apropriação privada das instituições públicas, diferente do que sugere a noção de "anarquia branca", cujo sentido é unidirecional, isto é, o privado modificando o público, Nunes Leal enfatiza a in- 
terdependência entre essas esferas, da qual resulta a própria dinâmica da vida política. Em suma, o coronelismo é uma "troca de proveitos entre o poder público, progressivamente fortalecido, e a decadente influência social dos chefes locais, notadamente dos senhores de terras" (Leal, 1997:40).

No plano analítico, portanto, em vez de permanecerem como um impasse, em Coronelismo, Enxada e Voto, público e privado influenciam-se mutuamente determinando o escopo das ações possíveis na vida política. Público e privado estão, pois, propriamente em uma relação de interdependência, no sentido de que nenhum dos dois isoladamente consegue adquirir um papel decisivo no processo político, isto é, determiná-lo na base dos seus valores ou interesses específicos. Nesse sentido, a pesquisa de Nunes Leal abre, de fato, novas perspectivas para a sociologia política, uma vez que sugere que são as formas particulares de articulação histórica entre público e privado que deveriam orientar a análise da vida política. Outra, contudo, seria a recepção da sua ênfase analítica na estrutura da dominação política, sintetizada na idéia de voto de cabresto, no programa de pesquisas de Maria Isaura Pereira de Queiroz.

\section{A "AGÊNCIA" SOCIAL ENTRE 0 PÚBLICO E O PRIVADO}

Maria Isaura Pereira de Queiroz é, dentre os autores destacados neste artigo, a única a, de fato, formular deliberadamente um programa para a sociologia política como área de pesquisa no Brasil ${ }^{11}$. Apresentado já no I Congresso Brasileiro de Sociologia, da Sociedade Brasileira de Sociologia -SBS, realizado na USP entre 21 e 27 de junho de 1954, "Contribuição para o Estudo da Sociologia Política no Brasil" lança e especifica um conjunto de tarefas nesse sentido, todas elas cumpridas pela socióloga paulista ao longo de pelo menos 20 anos de pesquisas desenvolvidas na USP. A primeira delas consistia na realização de estudos sociológicos historicamente orientados do passado político brasileiro que permitissem "fornecer um pano de fundo para os trabalhos efetuados sobre o presente, dando a visão de continuidade ou das transformações havidas na política" (Queiroz, 1976:17). Queiroz recusa, nesse sentido, a validade dos estudos realizados até então a esse respeito com o argumento de que, "de acordo com o ponto de vista liberal" por eles adotado, seriam meras "histórias das idéias políticas"; acentuando que ainda nos faltaria uma "história dos fatos políticos feita do ponto de vista sociológico, em que sejam encarados como produtos da vida 
em grupo" (idem:18). Como já observado, Queiroz não se refere a Oliveira Vianna, destaca apenas, no que diz respeito aos estudos até então existentes, Evolução Política do Brasil (1933) de Caio Prado Jr. como uma "tentativa" de interpretação do nosso passado político. Tentativa malsucedida, a seu ver, uma vez que o historiador paulista "fugira ao primeiro preceito sociológico que é observar antes de interpretar: fora ao campo munido da interpretação prévia através da luta de classes e tentara impô-la aos fatos brasileiros, quando só agora o Brasil desperta para essa luta" (Queiroz, 1976:18), avaliação com a qual, aliás, Oliveira Vianna provavelmente concordaria, tanto do ponto de vista teórico-metodológico, quanto substantivo (Vianna, 1973:157) ${ }^{12}$.

É nesse sentido, também, que Queiroz critica, no próprio âmbito dos debates do I Congresso da SBS, a comunicação nele apresentada por Alberto Guerreiro Ramos, uma vez que sua proposta implicaria "estudar a política brasileira através de idéias e não da própria realidade" (Anais, 1955:340). Crítica a que responde Guerreiro Ramos observando que "procurou mostrar em sua exposição como as idéias se relacionam com uma determinada situação social que sobre elas exerce pressão" (idem:342); proposição retomada, ao debater, por sua vez, a comunicação de Maria Isaura Pereira de Queiroz apresentada na sessão da tarde de 26 de junho. Registram os anais, nesse sentido, a sugestão de Guerreiro Ramos de que a formação de um "mercado nacional de bens e idéias" constituiria fator decisivo que alteraria "o sentido e a tendência da política brasileira, travando-se então o conflito entre as velhas forças defensoras da política de clientela e as novas forças que procuram exprimir-se ideologicamente" (idem: 349 ).

Em sua própria comunicação, "Esforços de Teorização da Realidade Nacional Politicamente Orientados, de 1870 aos Nossos Dias", posteriormente reunida em Introdução Crítica à Sociologia Brasileira, de 1957, Guerreiro Ramos recupera justamente a crítica de Oliveira Vianna ao "idealismo utópico" das elites brasileiras considerando-a "o máximo de objetividade que, até agora, os estudos sociológicos atingiram, entre nós" (Ramos, 1995:79); ressaltando, contudo, os limites da visão de Oliveira Vianna, que não teria percebido que a conduta idealista-utópica das elites "foi, muitas vezes, menos decorrência de uma imitação voluntária do que um expediente pragmático a que tiveram imperativamente de recorrer a fim de racionalizar ou justificar interesses e reivindicações de grupos e facções atrelados a tendências nem sempre ilegítimas da sociedade nacional" (idem:80). Proposição com a 
qual, como registram os anais do congresso, Paula Beiguelman teria concordado, enfatizando "a necessidade de superação de Oliveira Vianna [...] não tanto da obra em si, quanto das conclusões, que muitas vezes não estão contidas nas premissas apresentadas" (Anais, 1955:341). Observação em relação à qual Guerreiro Ramos se põe inteiramente de acordo, ressaltando ainda que "Oliveira Vianna negligenciou a historicidade do desenvolvimento econômico-social do Brasil, ao partir de uma concepção psicológica do processo social" (idem:343).

Assim, embora ausente especificamente do programa de Maria Isaura Pereira de Queiroz para a constituição da sociologia política no Brasil, Oliveira Vianna fez-se presente de modo nada aleatório no contexto em que seu programa fora originalmente apresentado e discutido junto à comunidade acadêmica dos anos 1950 no I Congresso Brasileiro de Sociologia. Além disso, e mais importante ainda, é possível apontar uma primeira e decisiva afinidade do programa de Queiroz com as proposições teórico-metodológicas de Oliveira Vianna. Na proposta da socióloga paulista de uma sociologia dos "fatos políticos" tratados como "produtos da vida em grupo" (Queiroz, 1976:18), ressoa, em grande medida, a própria autodefesa que Oliveira Vianna havia feito em relação à originalidade do método de análise por ele empregado em Populações Meridionais do Brasil. Afinal, o ensaísta fluminense já acentuava, como faria mais tarde Queiroz em relação a Caio Prado Jr., que partir de "doutrinas políticas" para tentar compreender a vida política não poderia redundar senão em conclusões "inteiramente falsas"; daí que tenha procurado fazer um estudo "concreto, objetivo, realístico", tratando das instituições políticas "ao vivo, tais como o povo as praticava realmente na sua vida cotidiana" (Vianna, 1973:298).

Em todo caso, em seus trabalhos posteriores, sobretudo em "O Mandonismo Local na Vida Política Brasileira", de 1969, e "O Coronelismo numa Interpretação Sociológica", de 1975, Maria Isaura Pereira de Queiroz procuraria justamente suprir aquela apontada ausência de sínteses sociológicas dos fatos políticos do passado brasileiro. Nesses trabalhos, estrutura sua investigação da dominação política não em torno da categoria de "classes", ou qualquer outra forma mais ampla de solidariedade social, mas na de "parentela". Para a socióloga paulista, as parentelas estariam na origem da estrutura da dominação política brasileira envolvendo formas de sociabilidade, conduta e solidariedade pessoalizadas em um núcleo extenso e espacialmente disperso de indivíduos unidos entre si por relações de parentesco de sangue, espi- 
ritual (compadrio) ou de alianças (uniões matrimoniais), relações econômicas e políticas, além de rivalidades e conflitos (Queiroz, 1976:181 e ss.). "Parentela" e "solidariedade parental", no entanto, também são noções já empregadas por Oliveira Vianna justamente para circunscrever, ao lado do "clã rural", a "única forma militante da solidariedade social em nosso povo" (Vianna, 1973:149). Enfatiza o ensaísta fluminense que a "solidariedade parental" encontrar-se-ia "tão enérgica ainda hoje nas zonas sertanejas" como no passado (ibidem), o que Queiroz pôde mesmo constatar em seus trabalhos de campo em Santa Brígida, distrito do município baiano de Jeremoabo, na década de 1950.

A segunda tarefa necessária à constituição da sociologia política como área de pesquisa no Brasil, apontada por Maria Isaura Pereira de Queiroz em sua comunicação ao I Congresso Brasileiro de Sociologia, consistiria na realização de estudos "concretos" sobre o presente que, confrontados às sínteses sociológicas do passado, pudessem dar a visão das continuidades ou descontinuidades na política (Queiroz, 1976:17). Para o cumprimento dessa segunda tarefa, a socióloga paulista realizou, de fato, trabalhos de campo em Santa Brígida, entre 1954 e 1959, cujos principais resultados foram apresentados em Sociologia e Folclore: A Dança de S. Gonçalo num Povoado Baiano, de 1958, e em "Política, Ascensão Social e Liderança num Povoado Baiano", este último originalmente apresentado como comunicação ao II Congresso Brasileiro de Sociologia em 1962. Mas também recuperados em "O Coronelismo numa Interpretação Sociológica" para se contrapor à tese de Vitor $\mathrm{Nu}$ nes Leal sobre o voto de cabresto e demonstrar seu argumento de que, no âmbito das relações de dominação do coronelismo, o voto integrava antes uma ampla e complexa rede de reciprocidades fundada na posse e escassez de "bens de fortuna" na qual a barganha política tornava-se possível (idem:168).

Se a caracterização das relações de dominação política envolvendo uma rede de reciprocidades assimétricas já havia sido formulada em Populações Meridionais do Brasil (Vianna, 1973:148 e ss.) e adotada por Nunes Leal para definir o coronelismo como "sistema" (Leal, 1997:64), nas pesquisas de Maria Isaura o problema ganha uma nova configuração sociológica com a introdução da dimensão da "agência" ou simplesmente da ação social. A marca da sociologia política de Queiroz está justamente, como sugere Glaucia Villas Bôas (2006), na tentativa de evidenciar que é na vida associativa que se encontram os motivos de compreensão das relações de "mando" e "obediência", concepção a 
partir da qual procura demonstrar a "racionalidade da política brasileira". Daí sua valorização da "experiência vivida" dentro dos grupos particulares de modo a se contrapor à tendência a avaliá-los somente a partir de modelos teóricos e de interpretações da sociedade global, bem como sua ênfase no caráter ativo da conduta humana para se contrapor à tendência a considerar as relações sociais como forças estranhas aos atores sociais, cujo significado lhes escapa à compreensão e mesmo ao controle ${ }^{13}$.

Como propõe Oliveira Vianna, Queiroz situa as relações de dominação política entre público e privado, como também havia feito Leal. E também como seus predecessores (Vianna, 1973:229-243; Leal, 1997), ela reconhece a necessidade de pesquisar as relações de dominação política a partir dos municípios, onde "o fenômeno político é mais violento e colore todos os outros aspectos da vida em grupo" (Queiroz, 1976:30). Todavia, procurando abordar as relações de dominação política não do ponto de vista do "sistema social" que elas formariam, como Leal, mas da perspectiva dos próprios atores sociais que as vivenciariam, Queiroz introduz uma série de distinções analíticas e históricas que lhe permite enfatizar a variedade e a multiplicidade de níveis daquelas relações em suas interações com diferentes estruturas sociais, econômicas e fundiárias - aspectos que, segundo sustenta, teriam sido subestimados por Victor Nunes Leal (idem:165). Realização paradigmática dessas proposições analíticas encontra-se em "Política, Ascensão Social e Liderança num Povoado Baiano".

A escolha de Queiroz pela pequena comunidade sertaneja de Santa Brígida esteve, de fato, guiada por dois motivos sociológicos principais sobre os quais já vinha argumentando desde o texto-programa de 1954. Em primeiro lugar, contrariando o que identificava como tendência a analisar a dominação política somente nas áreas litorâneas de monoculturas de exportação, buscava desvendar a diversidade de comportamentos políticos segundo as diferenças existentes "no próprio país, formando zonas geográfica, econômica e socialmente diferentes" (idem:30). Seus argumentos sobre o "voto como posse" contra o "voto de cabresto" estavam fundados justamente nas pesquisas empíricas realizadas naquela zona de sitiantes: nestas, a estrutura social tendia para uma configuração mais "igualitária", em contraste com as zonas de monoculturas de exportação ou de grandes criadores, nas quais, com base em uma estratificação social mais diferenciada e rígida, a dominação política do coronel seria mais direta e mesmo mais violenta 
(idem:176). Fundamental, nos casos em que a barganha política se tornava possível, seria o papel dos "cabos eleitorais" como nível intermediário da estratificação e dominação políticas que ligava aos coronéis os seus eleitores (idem:166). Em segundo lugar, é da perspectiva desses atores sociais, os cabos eleitorais, que a pesquisa se realiza, procurando dar conta das possibilidades de acesso à liderança política, acesso este considerado como uma forma de "ascensão social" em comunidades menos estratificadas.

Analisando as trajetórias de três cabos eleitorais de Santa Brígida, Maria Isaura Pereira de Queiroz conclui que, se o prestígio pessoal pode levar à liderança, é o "carisma" que, em uma comunidade tão pouco diferenciada internamente, parece constituir um "verdadeiro canal de ascensão social" (Queiroz, 1976a:116). É o caso do beato Pedro Batista, cabo eleitoral que ligava ao coronel do município os romeiros alagoanos por ele atraídos e estabelecidos em Santa Brígida. Ao beato, a quem chamavam de "Padrinho", os romeiros subordinavam-se "inteiramente" devido aos benefícios materiais e imateriais que sob sua liderança receberam, acreditando ainda que ele dispusesse de "dons sobrenaturais" comprovados pelo seu "poder terapêutico" (idem:110). Como no Padrinho dos romeiros inscrevem-se e entrelaçam-se dois princípios distintos de legitimação da dominação (Weber, 1992), o "tradicional", na autoridade pessoal que exerce, e o "carismático", manifesto na crença das suas qualidades extraordinárias, sua relação com os eleitores poderia até mesmo "independer de um esquema de dom e contradom" (Queiroz, 1976a:111).

Assim, se o voto integrava um "sistema" de trocas recíprocas nas áreas de pequenos produtores autônomos, as relações entre coronéis, cabos eleitorais e eleitores seriam realmente muito contingentes, pois nem "liderança" implicava posição de "superioridade", nem era em si mesma garantia suficiente de "ascensão social" nessas pequenas comunidades rurais. Com a reconstituição das trajetórias dos cabos eleitorais, Queiroz procura, portanto, especificar as condições sociais que orientam as condutas individuais e, desse modo, recuperar as diferentes respostas dos agentes submetidos às relações de dominação política do coronelismo - perspectiva a partir da qual, ao contrário do que uma investigação somente "sistêmica" teria permitido, se tornava possível, para a socióloga paulista, identificar o caráter dinâmico das relações de dominação política na sociedade brasileira. A vida social que se desenha em Santa Brígida a partir de suas pesquisas é, assim, ilustrativa 
da contingência das relações entre público e privado e das possibilidades e limites de ascensão social nos contextos de dominação pessoal, ponto que será retomado por Maria Sylvia de Carvalho Franco ao questionar, contudo, as possibilidades de negação da dominação política pessoal por parte dos "homens comuns" em geral.

\section{PÚBLICO E PRIVADO COMO UNIDADE CONTRADITÓRIA}

A primeira afinidade significativa entre Homens Livres na Ordem Escravocrata e Populações Meridionais do Brasil é a recusa em tratar a escravidão como um "modo de produção" que teria estruturado a sociedade brasileira, determinando todo o seu desenvolvimento posterior. Para Franco, a escravidão seria antes parte de um sistema socioeconômico mais amplo, "parte em que se pode encontrar, nem mais nem menos que em outra do sistema considerado, relações sociais em cujo curso se procede à unificação dos diferentes e contraditórios elementos nele presentes" (Franco, 1997:13, ênfases no original). Assim como no ensaísta fluminense, a ênfase analítica recai sobre as formas sociais assumidas pela grande propriedade fundiária no Brasil, especialmente no seu caráter quase autárquico, e na existência, no interior dos latifúndios, de áreas ociosas do ponto de vista da produção agrícola economicamente rentável direcionada para a exportação (idem:14). Essa estrutura socioeconômica desenvolvida desde a Colônia teria originado a formação de um grupo social específico entre senhores e escravos, estes últimos os responsáveis diretos pela produção agrário-exportadora ${ }^{14}$.

Nomeado como "plebe rural" por Oliveira Vianna, esse grupo social cuja origem e destino estariam diretamente associados às formas sociais assumidas pela propriedade fundiária ligava-se aos senhores rurais, como vimos, ao mesmo tempo de modo "frouxo", no plano econômico, e "militante" para efeitos políticos, sendo o paradoxo desta situação explicado pela "anarquia branca", isto é, a capacidade demonstrada pelos "clãs rurais" de apropriarem-se das instituições públicas existentes para a consecução dos seus interesses privados mobilizando, se necessário, recursos extremamente violentos nesse processo (Vianna, 1973:139 e ss.). Já nos termos de Franco, eles são "homens livres", a um só tempo "destituídos da propriedade dos meios de produção, mas não da sua posse, e que não foram plenamente submetidos às pressões econômicas decorrentes dessa condição, dado que o peso da produção, significativa para o sistema como um todo, não recai sobre seus ombros" (Franco, 1997:14). Pela dupla expropriação a que esse grupo so- 
cial estaria submetido, Maria Sylvia de Carvalho Franco fala de "homens a rigor dispensáveis, desvinculados dos processos essenciais à sociedade", uma vez que a "agricultura mercantil baseada na escravidão simultaneamente abria espaço para sua existência e os deixava sem razão de ser" (ibidem) - aspecto que também foi discutido por Oliveira Vianna (1973:127 e ss.). Em ambos os casos, assinalam-se, ainda, dificuldades decorrentes da dinâmica social formada a partir da existência desse contingente de homens livres pobres para a constituição de uma sociedade de classes no Brasil (Vianna, 1973:157; Franco, 1997:237).

Ao contrário de Oliveira Vianna, contudo, Maria Sylvia de Carvalho Franco recusa peremptoriamente qualquer idéia de "ambigüidade" ou "dualidade" para explicar a estrutura social produzida pelo latifúndio e a situação paradoxal dos homens livres pobres a ela diretamente associada. Na verdade, é justamente para se contrapor a esta idéia que põe em movimento suas pesquisas históricas e teóricas, e é essa a principal diferença de Homens Livres na Ordem Escravocrata em relação a Populações Meridionais do Brasil. Para Franco, no Brasil, ao contrário do que teria ocorrido em outros contextos históricos, a simultaneidade das duas "modalidades de produção" - para a subsistência e para o mercado - não apenas indicava que se tratava de práticas "interdependentes", uma vez que encontrariam "sua razão de ser na atividade mercantil", mas propriamente "constitutivas" uma da outra (Franco, 1997:11). Formariam antes uma "síntese" ou "unidade contraditória" que, "determinada na gênese do sistema colonial, sustentou, com suas ambigüidades e tensões, a maior parte da história brasileira" (ibidem). Por isso, em uma passagem que parece direcionada a Oliveira Vianna, argumenta que "a organização interna dos grandes estabelecimentos, per se, é insuficiente para caracterizá-los e para tornar inteligíveis as relações neles definidas" (Franco, 1997:197); e enfatiza que a "referência a essa organização interna alcança teor explicativo quando associada ao modo de produção capitalista, que dominava os mercados mundiais" (ibidem) ${ }^{15}$.

A pesquisa realizada por Maria Sylvia de Carvalho Franco refere-se à "velha civilização do café" compreendida na região do Vale do Paraíba fluminense e paulista do século XIX. Sua circunscrição empírica à comarca de Guaratinguetá, uma "área mais pobre da região paulista", foi orientada pela intenção de capturar os "nexos de recorrência entre estabilidade e mudança social", uma vez que nela as "transformações 
vindas com o café se fizeram sentir de maneira mais branda, conservando-se as características anteriores" (Franco, 1997:17). O material primário da pesquisa é composto basicamente por atas, correspondências e processos criminais da Câmara de Guaratinguetá do período de 1830 a 1899. Dele, mobiliza com destaque os processos-crime, e é especialmente a partir da análise dos relatos contidos nesses depoimentos dados à polícia que a socióloga paulista procura recuperar as "situações vividas" (idem:18) pelos homens livres e pobres.

Assim como para as demais pesquisas tratadas neste artigo, no que todas seguem o ensaio de Oliveira Vianna, também para Franco os homens livres pobres ganham inteligibilidade sociológica inseridos no âmbito da dominação marcada por relações diretas, pessoais e violentas que formam uma rede de contraprestações de toda sorte de serviços prestados e favores recebidos. A esse respeito, no entanto, Homens Livres na Ordem Escravocrata apresenta contribuições notáveis. Em primeiro lugar, mostra como a violência característica das relações de dominação pessoal é constitutiva, também, das relações de solidariedade social internas aos grupos considerados, como mostra de modo paradigmático a análise dos mutirões como forma cooperativa de trabalho entre os "caipiras" (idem:21 e ss.). A esse respeito, por exemplo, Maria Isaura Pereira de Queiroz, tal como Oliveira Vianna e Victor Nunes Leal, enfatiza a violência engendrada nas relações políticas entre os diferentes grupos sociais, ou, como diz, mais de uma "metade" para a outra, "do que no interior dos grupos", muito embora, citando justamente Homens Livres na Ordem Escravocrata para fazer a ressalva, reconheça que a violência não estivesse ausente também na dimensão intragrupal (Queiroz, 1976:179).

Em segundo lugar, a análise de Maria Sylvia de Carvalho Franco dá atenção especial ao sentido sociológico das componentes sociais intersubjetivas presentes nas relações de dominação política pessoalizadas. A "dominação pessoal" sustentada nas relações de contraprestação é "pessoal", argumenta a autora, justamente porque fundada em uma identificação entre aqueles que delas participam como "pessoas", categoria que cria uma aparência de indistinção social corroborada ainda pelo "estilo de vida" simples da região desde o início do século XIX, quando a situação de penúria das condições materiais era praticamente generalizada (Franco, 1997:115-119). Por isso, as relações de dependência aparecem antes como uma "inclinação de vontades no mesmo sentido, como harmonia, e não como imposição da vontade do mais 
forte sobre a do mais fraco, como luta. Em conseqüência, as tensões inerentes a essas relações estão profundamente ocultas, havendo escassas possibilidades de emergirem à consciência dos dominados" (idem:95). O compadrio, por exemplo, é uma relação paradigmática da dominação pessoal porque permite ou mesmo exige uma quebra aparente das hierarquias sociais entre aqueles que, pelo batismo, são unidos ritualmente num "parentesco divino" (idem:84-86). Essa aparência de "igualdade" conferida pela categoria "pessoa" aos homens livres pobres, por oposição aos escravos vistos como "propriedade" ou "coisa", é fundamental porque suas relações com os senhores não são vividas diretamente como uma relação de dominação. Não apenas entre sitiantes e fazendeiros, mas também entre estes e seus agregados ou até mesmo com outras categorias sociais virtualmente menos dependentes deles, como tropeiros e vendeiros, todas elas submetidas à mesma trama de relações de fidelidades pessoais (idem:65-114). Tal qual, mais uma vez, as bases sociais da dominação política foram discutidas por Oliveira Vianna (1973:127 e ss.), ainda que Franco, como Queiroz, assinale a possibilidade de ascensão social em termos estritamente individuais naqueles grupos sociais virtualmente menos dependentes (Franco, 1997:65-114).

Ainda que não veja na dominação política, como Oliveira Vianna propõe, exatamente uma contrapartida para a fragilidade dos laços socioeconômicos que ligam os senhores rurais ao vasto contingente de homens livres pobres, Franco também considera a política uma área privilegiada para observar as relações de "dependência" dos grandes proprietários em relação aos seus "vizinhos menores" (idem:90). Mais do que isso, divisa na importância vital assumida na vida política por essa relativa sujeição do senhor, traduzida numa série de obrigações da sua parte, o principal motivo que desautorizaria uma caracterização da dominação pessoal em termos de uma relação "patrimonial típica" tal como definida por Max Weber (idem:91). Mas como Oliveira Vianna, no entanto, para quem "a natureza da solidariedade social produzida pela patronagem política define-se pela sua assimetria" (Werneck Vianna, 1993:377), também Franco enfatiza a desigualdade de poder envolvida nas relações de dominação pessoal, sustentando, além disso, que esse tipo de situação constituiria uma base social pouquíssimo "propícia para a orientação racional da ação" (Franco, 1997:29).

Aqui, Franco se afasta de Queiroz e sua caracterização da "racionalidade" da política. Ainda que Queiroz sublinhe, ao tratar do voto, que este 
é "consciente, mas orientado de maneira diversa do que é o voto de um cidadão de sociedade diferenciada e complexa": no primeiro caso, argumenta, "o voto é um bem de troca"; no segundo, "é a afirmação pessoal de uma opinião" (Queiroz, 1976:178). Para Franco, ao contrário, um dos principais efeitos sociais da dominação pessoal seria justamente a "asfixia da consciência política" (Franco, 1997:89), situação na qual o voto não encontraria sequer "condições para se expressar em mercadoria nem podia ser o resultado de uma autodeterminação enraizada na consciência de interesses autônomos" (idem:88). Aproximando-se da caracterização das eleições de Leal (1997), Franco enfatiza que mais do que na "manipulação do eleitorado" ou no "aliciamento de prosélitos", as técnicas empregadas para conquista e manutenção do poder político incidiam antes no "processamento e no resultado das eleições" (Franco, 1997:87).

Embora com discordâncias significativas em relação a algumas questões substantivas, a pesquisa de Franco apresenta até aqui afinidades decisivas no plano metodológico com o programa de sociologia política de Maria Isaura Pereira de Queiroz, quer pela eleição do "grupo social" como ponto de partida da análise (capítulo 1) para depois tratar da sua relação com a sociedade inclusiva (capítulo 2), quer pela ênfase nas situações "vividas" pelos homens comuns em suas ações cotidianas. Seu desenvolvimento a partir daí, contudo, procurando dar conta de problemas de ordem macrossociológica, acaba permitindo que Maria Sylvia de Carvalho Franco demonstre que a "dominação pessoal" é incorporada de modo constitutivo às instituições públicas (capítulo 3) e às transformações econômicas necessárias à integração da produção agrícola brasileira aos mercados internacionais (capítulo 4). Destaco sua argumentação de que a dinâmica da sociedade definida pela "dominação pessoal" cria e recria as instituições públicas, ao longo da qual a autora também se aproxima das preocupações de Oliveira Vianna com a dimensão institucional da dominação política e, particularmente, com os mecanismos sociais de apropriação privada das instituições públicas expressa na noção de "anarquia branca" (Vianna, 1973:139 e ss.). Ainda que, ao contrário do ensaísta fluminense, a análise de Franco dos processos sociais "subjacentes" à constituição e consolidação do Estado nacional e de seu aparato burocrático no século XIX procure se realizar do ponto de vista em que tais processos teriam sido "vividos pelo homem comum" (Franco, 1997:165). 
Partindo, como assinalou Werneck Vianna (1999:184), da tese de Max Weber sobre a singularidade da burocracia ocidental moderna, Franco entende que o processo de organização burocrática do Estado brasileiro na primeira metade do século XIX esteve fundado "formalmente no princípio burocrático de obediência a um poder público abstratamente definido, legitimado e expresso por normas racionalmente criadas e legalmente estatuídas" (Franco, 1997:121). Para o assentamento da autoridade pública, tratava-se, ao lado do emprego da força física e da guerra, de concentrar o aparelho tributário dispondo de um "corpo de agentes disciplinados para o exercício metódico e despersonalizado das funções públicas" (ibidem). Mas a burocratização da administração pública não se fazia num vazio de relações sociais e, mais do que isso, encontrava nas mesmas relações que a haviam tornado necessária os seus próprios limites. Em sua interação com a sociedade, a burocratização era rivalizada por fatores tão poderosos quanto o próprio princípio racional-legal que, formalmente, a animava. O servidor público do município sintetiza exemplarmente a disputa que então se trava pela orientação das condutas de indivíduos e grupos sociais entre, de um lado, aquele princípio abstrato e longínquo, e, de outro, os "fortes interesses e influências que envolviam a sua vida de maneira imediata" (ibidem). Nessa disputa entre solidariedades sociais, vence o pragmatismo que prendia o servidor público à sua sociedade local.

São principalmente duas as razões apontadas, com base nos materiais de pesquisa coligidos por Franco, para a demarcação pouco nítida entre as atividades privadas e públicas no âmbito das instituições do Estado. Em primeiro lugar, a precariedade com que as ordenações administrativas estavam estabelecidas em termos "positivos" e, portanto, sua fragilidade normativa para o conjunto da sociedade favoreciam a que o servidor público, no cumprimento de suas funções, continuasse orientando sua conduta no cotidiano pelo que o costume já havia assentado (Franco, 1997:122-125). O outro fator decisivo do desenvolvimento da burocracia na administração pública, seguindo mais uma vez Max Weber, também ausente no Brasil do século XIX, foi, segundo Franco, o processo de "expropriação do servidor público dos meios materiais de administração, separando-se com nitidez os recursos oficiais dos bens privados dos funcionários" (idem:130). Ausência devida à própria situação de penúria em que o Estado se encontrava e agravada pela política financeira do Império marcada por extrema concentração das rendas públicas (idem:128). 
Diante dessa situação paradoxal - já que a própria penúria da administração pública que havia levado, desde 1834, à reorganização do aparelho tributário do Estado, impedia que esse processo se consumasse em termos tipicamente burocrático-racionais -, a solução encontrada foi o "apelo direto ao patrimônio particular do cidadão comum ou do próprio servidor público" (ibidem). Tal solução não apenas discrepava totalmente dos procedimentos característicos de uma ordem burocrático-racional, como reforçava o exercício personalizado do poder e o controle pessoal do patrimônio do Estado, pois, nessas condições, argumenta Maria Sylvia de Carvalho Franco, em vez de o servidor público tornar-se progressivamente um "executivo que apenas gere os meios da administração, manteve-se preservada a situação em que ele os podia controlar autonomamente, pois ele os possuía" (Franco, 1997:131, ênfases no original).

A articulação entre a debilidade material dos poderes públicos, o uso privativo dos aparelhos governamentais e as técnicas pessoais de dominação, portanto, fundem público e privado. E este entrelaçamento de esferas sociais distintas, por sua vez, constitui a própria condição da dominação pessoal, enquanto princípio mais geral de regulação das relações sociais no Brasil. Ou por outra, aquela "unidade contraditória" identificada no interior do latifúndio, ganhando a sociedade através da dominação pessoal, desdobra-se na própria organização do Estado, unindo necessariamente público e privado (idem:240). Nessas condições, como pensar a ruptura por parte dos grupos sociais subalternos da condição de "dominação pessoal" a que estavam submetidos se esta constituía o princípio geral de organização institucional da sociedade? Essa demonstração de Maria Sylvia de Carvalho Franco de que a dinâmica da sociedade recria as instituições políticas e que, portanto, também público e privado formam uma "unidade contraditória" e não uma "oposição" ou "dualidade" é também o ponto de chegada desta investigação.

\section{CONSIDERAÇÕES FINAIS}

Reconstituindo analiticamente a agenda de pesquisas formada em torno da problemática da dominação política no Brasil desde Populações Meridionais do Brasil até Homens livres na Ordem Escravocrata, passando por Coronelismo, Enxada e Voto e diferentes pesquisas de Maria Isaura Pereira de Queiroz, procurou-se neste artigo identificar as linhas centrais de continuidade e descontinuidade cognitivas de uma vertente 
da sociologia política brasileira en train de se faire entre os anos 1920 e 1970. No plano das continuidades, argumentou-se que as pesquisas mantêm, em primeiro lugar, a tese central do ensaio de Oliveira Vianna sobre a configuração histórica particular das relações de dominação política no Brasil fundada no conflito entre as ordens privada e pública e não diretamente assimilável ao conflito de classes enraizado no mundo da produção; bem como, em segundo lugar, sua tendência teórico-metodológica a relacionar a aquisição, distribuição, organização e exercício de poder político à estrutura social com o objetivo de identificar as bases e a dinâmica da política na própria vida social.

Com relação ao primeiro aspecto dessa continuidade entre as pesquisas destacadas e o ensaio de Oliveira Vianna, pode-se dizer que a agenda de pesquisas aqui reconstituída diferencia-se, substantivamente, de outras tradições intelectuais que também vêm sendo identificadas como "sociologia política" nas ciências sociais brasileiras. Como a formada a partir da cadeira de Sociologia I da USP, fortemente marcada, por sua vez, pela associação entre dominação política e conflito de classes, bem como pelas questões da dependência e do desenvolvimento econômicos brasileiros (Sallum Jr., 2002). Certamente, o privilégio analítico, já presente em Oliveira Vianna, que as pesquisas de Leal, Queiroz e Franco concedem às relações entre público e privado na definição da dominação política no Brasil não exclui totalmente sua associação às relações econômicas, embora a delimitação do econômico em relação às demais esferas da sociedade assuma sentidos diferentes em cada uma delas. Como vimos, Leal relaciona o fortalecimento do público à decadência econômica do latifúndio. Queiroz circunscreve sua abordagem das relações de dominação política às áreas de pequenos sitiantes sertanejos, tendo em vista também suas diferenças em termos de configuração socioeconômica em relação às áreas de monoculturas para exportação. E se Franco recusa tomar a escravidão como modo de produção, sua abordagem só ganha inteligibilidade a partir da sugestão da presença simultânea, no interior do latifúndio, da produção para a subsistência e para o mercado como práticas "constitutivas" uma da outra; questão que se desdobra teoricamente em sua tese de livre-docência, O Moderno e suas Diferenças (1970), até a afirmação de que, na sociedade brasileira, "os critérios extra-econômicos de categorização dos indivíduos em sociedade aparecem, reiteradamente, perturbados pelos critérios de diferenciação social fundados em situação econômica" (Franco, 1970:177). 
Já quanto ao segundo aspecto de continuidade na vertente da sociologia política aqui reconstituída, pode-se dizer que os trabalhos analisados convergem, no plano teórico-metodológico, para uma abordagem que se quer especificamente sociológica da política; a qual, no lugar de uma lógica institucional autônoma que caracteriza, em grande medida, a demarcação disciplinar tardia da ciência política no Brasil (Lamounier, 1982), privilegia a investigação das bases sociais da vida política, suas relações com a estrutura social e com as condições sociais do protagonismo dos diferentes atores coletivos. Daí, o significado heurístico dessa vertente da sociologia brasileira para a compreensão dos desafios da democracia; afinal, ao correlacionar estrutura social do mundo agrário e relações de dominação política e ao problematizar a interação entre a capacidade de ação de indivíduos e grupos e o condicionamento de estruturas sociais, também ela coloca em discussão a problemática das bases sociais da democracia, para retomar formulação que se tornou clássica na sociologia política (Moore Jr., 1983).

Com relação, por sua vez, às descontinuidades cognitivas internas entre os diferentes trabalhos que compõem a vertente da sociologia política brasileira aqui reconstituída, são distintas, sobretudo, as concepções de sociedade que assumem e que procuram conferir verossimilhança com os próprios resultados obtidos no estudo da constituição, organização e reprodução das relações de dominação política. No caso de Oliveira Vianna, a caracterização destas permanece dependente de uma visão dualista das relações entre público e privado e, assim, da própria sociedade; visão que, se não leva necessariamente à construção do consenso em detrimento do conflito, acaba por circunscrever este último ao âmbito das relações entre Estado e sociedade, subsumindo, desse modo, a própria desigualdade de poder que está na base das relações entre os diferentes grupos sociais, o que se pode depreender não apenas da sua ênfase na necessidade de uma nova moralidade unitária coordenadora das relações sociais que ele entrevê no fortalecimento e centralização do Estado, como também da sua caracterização do "insolidarismo social" entre os indivíduos e grupos sociais para além dos círculos privados, como uma das principais conseqüências do baralhamento entre público e privado no Brasil ${ }^{16}$.

Como vimos, por outro lado, a análise de Victor Nunes Leal do coronelismo introduz a noção de "sistema" para mostrar que nem o privado se sobrepõe inteiramente ao público nem esses princípios diferentes de coordenação social se encontrariam numa relação de oposição; mas an- 
tes, enquanto forma de dominação, o coronelismo supõe um compromisso entre um poder privado decadente e um poder público progressivamente fortalecido em uma relação de interdependência no sentido de que nenhum dos dois isoladamente consegue determinar o processo político na base dos seus valores ou interesses específicos. Ainda que não seja estática ou dotada de propriedades independentes do processo histórico, tampouco exclua os atores sociais que dele participam de modo constitutivo, a noção de "sistema" formado por público e privado determina em Coronelismo, Enxada e Voto o escopo das ações possíveis no âmbito da dominação política.

Maria Isaura Pereira de Queiroz, por sua vez, sobretudo com base em trabalhos de campo, busca evidenciar em uma versão não-voluntarista, porque também atenta aos condicionantes e variáveis estruturais, as possibilidades e limites da ação individual no interior da estrutura da dominação política do coronelismo, por mais diversas que fossem, como faz questão de acentuar. As possibilidades de ascensão socioeconômica individual e do uso do voto como "posse" para uma barganha política na estrutura coronelística expressam em suas pesquisas como as relações de dominação política, constituídas entre o privado e o público, podem produzir comportamentos em indivíduos e grupos sociais e não apenas restringir e controlar o escopo de suas ações. Teoricamente, a introdução da problemática da "agência" permite-lhe, portanto, enfatizar a capacidade manifesta por indivíduos e grupos sociais de agirem e, desse modo, responderem ao contexto de estruturas de dominação em que se inserem.

Por fim, Maria Sylvia de Carvalho Franco mostra que a "dominação pessoal" é incorporada, enquanto princípio mais geral de regulação das relações sociais, de um modo constitutivo às instituições políticas, o que se manifesta, fundamentalmente, no "exercício personalizado do poder". E porque é a dinâmica da sociedade que cria e recria as instituições políticas, procura, portanto, dirimir qualquer dúvida quanto ao fato de que, no Brasil, público e privado fundem-se formando mesmo uma "unidade contraditória" e não uma "oposição" ou "dualidade". Com Homens Livres na Ordem Escravocrata temos, talvez, a tentativa mais consistente, dentre os trabalhos destacados, de articular as dimensões da "ação" e da "estrutura" em um movimento analítico que procura dar conta tanto da socialização dos atores na dominação pessoal, quanto da sua institucionalização. Mesmo realizando sua explicação sociológica da formação do Estado do ponto de vista em que o 
processo teria sido vivido pelo "homem comum", aquela articulação, segundo a própria autora, pôde ser atingida ao colocar, no centro da análise das relações entre "mundo objetivo" e "subjetividade", o conceito de "práxis" visando superar "velhos fantasmas como indivíduo e sociedade" (Franco, 1997:16, ênfases no original).

Em suma, com relação ao ensaio de Oliveira Vianna, as pesquisas de Victor Nunes Leal, Maria Isaura Pereira de Queiroz e Maria Sylvia de Carvalho Franco introduzem descontinuidades cruciais por dentro dos próprios desdobramentos analíticos que direta ou indiretamente realizam. Embora elas partam da tese do papel do baralhamento entre público e privado na constituição, organização e reprodução das relações de dominação política, acabam por rejeitar, cada uma a seu modo, a perspectiva dualista formulada por Oliveira Vianna, bem como a alegação, em parte dela derivada, do "insolidarismo social" como um ethos dos brasileiros, perspectiva que levou às hipóteses ou de uma incompatibilidade intrínseca do Brasil em relação à democracia, ou da centralidade do papel do Estado em seu estabelecimento e direção. Embora também tenham constatado em diferentes frentes a restrição ou a preponderância da solidariedade social à esfera privada, as pesquisas de Victor Nunes Leal, Maria Isaura Pereira de Queiroz e Maria Sylvia de Carvalho Franco não corroboram a tese de que isso configuraria um impasse intransponível à constituição de uma ordem pública no Brasil ${ }^{17}$. Mas tampouco permitem concluir que o baralhamento e as tensões entre público e privado não tivessem conseqüências para a democracia. Sem subestimá-las, mostram que a sociedade brasileira não estava - nem poderia ficar - em suspenso à espera de resoluções puramente institucionais para suas tensões socialmente constitutivas, e assim acabam por contribuir para uma reorientação do interesse analítico da sociologia política para as formas históricas, concretas e contingentes da articulação entre público e privado na sociedade brasileira.

Com este artigo, enfim, espera-se ter sugerido que a análise comparativa e cumulativa entre ensaio e pesquisa sociológica como especialidade acadêmica pode contribuir efetivamente para a continuidade do conhecimento da história das ciências sociais no Brasil em um plano propriamente cognitivo. É inegável que as interpretações de Victor Nunes Leal, Maria Isaura Pereira de Queiroz e Maria Sylvia de Carvalho Franco a um só tempo expressam e se beneficiam dos avanços teórico-metodológicos contemporâneos internacionais da disciplina, mas o destaque analítico dado à recepção crítica das idéias de Oliveira Vianna 
em suas pesquisas permite reconhecer que, também no âmbito das ciências sociais, estava em formação um "sistema de problemas e contradições que de modo nenhum excluía, mas filtrava a oferta internacional de teorias sociais" (Schwarz, 1999:20). É certo também que a comparação entre ensaio e pesquisa sociológica não deve levar, necessariamente, a um entendimento da formação dessa vertente da sociologia política meramente em termos evolutivos lineares. Nesse sentido, quero sustentar que cada um dos estudos que compõem a agenda de pesquisa analisada neste artigo tem não apenas autonomia e validade independentes uns dos outros, e de acordo com os diferentes objetivos e compromissos que apresentam, como também que o reconhecimento de que formam um conjunto analítico e que, assim considerados, expressam conquistas cognitivas heurísticas cruciais da sociologia, não invalida o caráter conflituoso e concorrente das suas perspectivas entre si. A abordagem analítica proposta neste estudo justifica-se, então, fundamentalmente, tendo em vista que, sendo o sentido da construção do conhecimento sociológico cumulativo, ainda que cronicamente não-consensual (Giddens, 1998; Alexander, 1999; Domingues, 2004), o reexame constante de suas realizações passadas, inclusive através da exegese de textos, assume papel muito mais do que tangencial na prática corrente da disciplina. Este reexame, dado inclusive que os desafios atuais de qualquer sociedade estão associados também à sequiência do seu desenvolvimento histórico, pode concorrer para que, parafraseando Reinhard Bendix (1996:36), "os insights obtidos no passado" não sejam "descartados levianamente", como no caso das proposições da sociologia política aqui reconstituída face à construção social contemporânea da democracia no Brasil.

(Recebido para publicação em dezembro de 2006)

(Versão definitiva em março de 2007) 


\section{NOTAS}

1. A respeito da produção em livros das ciências sociais brasileiras entre 1945 e 1966 sobre a vida política nacional, ver Villas Bôas (1992).

2. Por "contexto intelectual" entende-se o "contexto das obras anteriores e dos axiomas herdados a propósito da sociedade política, bem como o contexto das contribuições mais efêmeras da mesma época ao pensamento social e político. Pois é evidente que a natureza e os limites do vocabulário normativo disponível em qualquer época dada também contribuirão para determinar as vias pelas quais certas questões em particular virão a ser identificadas e discutidas" (Skinner, 1999:10-11).

3. É controversa, e não conclusiva, a questão da denominação de "sociologia política" no Brasil, se como ramo especializado da sociologia, ou se como disciplina independente, ou ainda se diferente, e em que termos, da ciência política. Um mapeamento desse debate, com várias posições, encontra-se em Scherer-Warren e Benakouche (2002). Retomo, para meus propósitos, a sugestão de Elisa Reis segundo a qual mais do que um problema de definição de fronteiras disciplinares, sempre mais ou menos arbitrárias e instáveis, a investigação de sua "tradição de pesquisa", incluídas as relações com os seus "clássicos", abre possibilidades efetivas de compreensão da sociologia política e dos desafios específicos aos quais ela procura responder (Reis, 1999).

4. Como sugere Elide Rugai Bastos, o "pensamento de Oliveira Vianna está presente, ou mesmo adquire novos desenvolvimentos na obra de outros cientistas sociais"; lembra ainda que "aqueles que se colocam criticamente, em face das interpretações e diretrizes apresentadas por Oliveira Vianna em seus escritos, também esses são obrigados a estabelecer um diálogo aberto ou implícito com ele" (Bastos, 1993:7).

5. Ver Santos (1978); os diferentes trabalhos reunidos em Bastos e Moraes (1993); e, para uma exposição sistemática de Populações Meridionais do Brasil, Brandão (2001).

6. E a "luta de classes", pondera Oliveira Vianna, constituiria não apenas uma "das maiores forças de solidariedade nos povos ocidentais, como a melhor escola da sua educação cívica e da sua cultura política" (Vianna, 1973:157).

7. Para uma exposição detalhada da questão da restrição da solidariedade social ao âmbito privado em Oliveira Vianna, ver Botelho e Brasil (2005).

8. A partir desse plano mais amplo, outras confluências cognitivas significativas podem ser identificadas na vertente da sociologia política destacada, tais como os impasses para a ação coletiva, o munícipio como lócus da política, a centralidade das relações do poder local com o Estado nacional, a violência como código social e expressão da dificuldade de assentamento da autoridade pública, a apropriação das instituições públicas para fins privados, entre outros.

9. No que se refere ao pensamento social brasileiro, cabe observar que, embora não ocupe o mesmo lugar analítico e tampouco o mesmo sentido político de uma interpretação para outra, a tese sobre o baralhamento entre público e privado está centralmente presente no ensaísmo da década de 1930, especialmente em Casa-Grande E Senzala (1933), de Gilberto Freyre, Raizes do Brasil (1936), de Sergio Buarque de Holanda, e A Ordem Privada e a Organização Política Nacional (1939), de Nestor Duarte.

10. O que leva José Murilo de Carvalho a afirmar com razão que o livro não se inscreve diretamente na "tradição feudalista" que teria em Oliveira Vianna e Nestor Duarte 


\section{André Botelho}

seus "mais ilustres representantes" e, entre seus seguidores, Maria Isaura Pereira de Queiroz e Costa Pinto (Carvalho, 1998:140). Todavia, como o objetivo do estudo é mapear não apenas as continuidades, mas as descontinuidades na agenda de pesquisas en train de se faire entre as décadas de 1920 e 1970, não parece inadequado destacar o "diálogo" que, repita-se, não implica concordância, também de Victor Nunes Leal como Populações Meridionais do Brasil. Para uma exposição sistemática de Coronelismo, Enxada e Voto, ver Lamounier (1999).

11. Para uma exposição sistemática da sociologia política de Maria Isaura Pereira de Queiroz, ver Villas Bôas (2006).

12. Embora sugira que o fenômeno realmente "novo" da política brasileira seria o "desaparecimento da solidariedade familial" face ao reconhecimento das "diferenças de interesses das diversas camadas da população" - ainda que não se pudesse associar esse reconhecimento diretamente ao surgimento de uma "solidariedade de classes" (Queiroz, 1976:28), Queiroz afirma que a "linha de continuidade interna de nossa política" se evidenciaria, nos dias atuais, no surgimento de um tipo novo de coronelismo: o "coronelismo urbano" (idem, 1976:29).

13. Assinale-se a afinidade do interesse analítico de Queiroz pelos pequenos produtores rurais, pela idéia de rusticidade como característica distintiva desses grupos, pela ênfase no trabalho de campo como forma de controle das generalizações teóricas e, sobretudo, pela tendência a valorizar a "auto-reflexão" dos grupos estudados, e a tradição sociológica de Os Parceiros do Rio Bonito (1954) de Antonio Candido (Jackson, 2002). Trata-se, como o próprio Candido assinalou, embora não se refira ao seu trabalho, de um movimento de deslocamento / rotação ao mesmo tempo metodológico e ético operado pela sociologia da USP em relação à perspectiva "senhorial", característica da abordagem de Oliveira Vianna, com a introdução do "homem comum" no centro do seu interesse analítico (Candido, 2004:233). Para outros aspectos da obra de Queiroz, ver Kosminsky (1999).

14. Sem minimizar a importância que a escravidão assume na formação da população "livre", a ênfase analítica na questão fundiária, na mesma medida em que aproxima a pesquisa de Franco de Oliveira Vianna a afasta das pesquisas típicas da chamada "escola sociológica paulista", as quais tomam as relações entre senhores e escravos como eixo explicativo da formação social brasileira (Bastos, 2002).

15. No que então Franco se aproxima da interpretação do Brasil de Caio Prado Jr. e da própria tradição sociológica da Cadeira de Sociologia I da USP. Sobre a articulação do estudo da sociedade brasileira a uma configuração histórica mundial nessa tradição sociológica, ver Bastos (2002).

16. Assinale-se, nesse sentido, que a caracterização sociológica de Populações Meridionais do Brasil do processo de formação da sociedade não encontra correspondência quando se trata da dimensão da ação social. Sempre que esta se insinua, por força da argumentação, constrangimentos de diferentes ordens extra-sociais, não decisivos na caracterização do processo, são habilmente mobilizados para restringir as suas possibilidades efetivas.

17. Para a discussão sobre as relações entre público e privado na modernização da política brasileira do século XX, ver Gomes (1998). 


\section{REFERÊNCIAS BIBLIOGRÁFICAS}

ALEXANDER, Jeffrey C. (1999), "A Importância dos Clássicos", in A. Giddens e J. Turner (orgs.), Teoria Social Hoje. São Paulo, Editora Unesp, pp. 23-90.

ANAIS DO I CONGRESSO BRASILEIRO DE SOCIOLOGIA. (1955), São Paulo, Sociedade Brasileira de Sociologia.

BASTOS, Elide Rugai. (1993), “Apresentação”, in E. R. Bastos e J. Q. de Moraes (orgs.), O Pensamento de Oliveira Vianna. Campinas, Editora da Unicamp, pp. 7-10.

(2002), "Pensamento Social da Escola Sociológica Paulista”, in S. Miceli, O que Ler na Ciência Social Brasileira, 1970-2002. São Paulo/Brasília, Anpocs/Sumaré/Capes, pp. 183-232.

e MORAES, João Quartim de. (orgs.). (1993), O Pensamento de Oliveira Vianna. Campinas, Editora da Unicamp.

BENDIX, Reinhard. (1996), Construção Nacional e Cidadania. São Paulo, Edusp.

BOTELHO, André e BRASIL, Antonio. (2005), “Das Sínteses Difíceis: Espírito, Clã, Cordialidade e Estado-Nação no Brasil". Matiz Revista de Ciências Humanas e Aplicadas, vol. 1, pp. 173-210.

BRANDÃO, Gildo Marçal. (2001), “Oliveira Vianna: Populações Meridionais do Brasil”, in L.D. Mota (org.), Introdução ao Brasil. Um Banquete no Trópico, vol. 2. São Paulo, Senac, pp. 299-326.

. (2005), "Linhagens do Pensamento Político Brasileiro". Dados, vol. 48, no 2, pp. 231-269.

BRESCIANI, Maria Stela M. (2005), O Charme da Ciência e a Sedução da Objetividade. Oliveira Vianna entre Intérpretes do Brasil. São Paulo, Editora Unesp.

CANDIDO, Antonio. (2004), "A Faculdade no Centenário da Abolição", in Vários Escritos. São Paulo/Rio de Janeiro, Duas Cidades/Ouro sobre Azul, pp. 227-240.

CARVALHO, José Murilo de. (1993), "A Utopia de Oliveira Vianna”, in E.R. Bastos e J.Q. Moraes (orgs.), O Pensamento de Oliveira Vianna. Campinas, Editora da Unicamp, pp. $13-42$.

. (1998), "Mandonismo, Coronelismo, Clientelismo: Uma Discussão Conceitual", in Pontos e Bordados: Escritos de História e Política. Belo Horizonte, Editora UFMG.

DOMINGUES, José Maurício. (2004), Teorias Sociológicas no Século XX. Rio de Janeiro, Civilização Brasileira.

FRANCO, Maria Sylvia de Carvalho. (1970), O Moderno e Suas Diferenças. Tese de Livre-Docência. Departamento de Ciências Sociais/Faculdade de Filosofia, Letras e Ciências Humanas, Universidade de São Paulo.

(1997) [1964], Homens Livres na Ordem Escravocrata (4a ed.). São Paulo, Editora Unesp.

GIDDENS, Anthony. (1998), Política, Sociologia e Teoria Social. São Paulo, Editora Unesp. 


\section{André Botelho}

GOMES, Ângela de Castro. (1998), “A Política Brasileira em Busca da Modernidade: Na Fronteira entre o Público e o Privado", in L.M. Schwarcz (org.), História da Vida Privada no Brasil, São Paulo, Companhia das Letras, vol. IV, pp. 489-558.

JACKSON, Luiz Carlos. (2002), A Tradição Esquecida. Os Parceiros do Rio Bonito e a Sociologia de Antonio Candido. Belo Horizonte, Editora UFMG.

KOSMINSKY, Ethel. (org.) (1999), Agruras e Prazeres de uma Pesquisadora: A Sociologia de Maria Isaura Pereira de Queiroz. Marília/São Paulo, Editora Unesp/Marília Publicações/Fapesp.

LAMOUNIER, Bolívar. (1982), “A Ciência Política no Brasil: Roteiro para um Balanço Crítico", in B. Lamounier (org.), A Ciência Política nos Anos 80. Brasília, Editora UnB.

(1999), "Victor Nunes Leal. Coronelismo, Enxada e Voto", in L.D. Mota (org.), Introdução ao Brasil. Um Banquete no Trópico. São Paulo, Senac, pp. 273-292.

LEAL, Victor Nunes (1997) [1949]. Coronelismo, Enxada e Voto: O Município e o Sistema Representativo no Brasil (3a ed.). Rio de Janeiro, Nova Fronteira.

MOORE JR., Barrington. (1983), Origens Sociais da Ditadura e da Democracia. São Paulo, Martins Fontes.

QUEIROZ, Maria Isaura Pereira de. (1958), Sociologia e Folclore: A Dança de S. Gonçalo num Povoado Baiano. Salvador, Fundação para o Desenvolvimento da Ciência na Bahia.

. (1976), O Mandonismo Local na Vida Política Brasileira e Outros Ensaios. São Paulo, Alfa-Ômega.

. (1976a) [1962], “Política, Ascensão Social e Liderança num Povoado Baiano", in O Campesinato Brasileiro: Ensaios sobre Civilização e Grupos Rústicos no Brasil. Petrópolis, Vozes, pp. 100-122.

RAMOS, Alberto Guerreiro. (1995), Introdução Crítica à Sociologia Brasileira. Rio de Janeiro, Editora UFRJ.

REIS, Elisa Pereira. (1999), "Os Velhos e os Novos Desafios da Sociologia Política”, in J.V.T. dos Santos (org.), A Sociologia para o Século XXI. Pelotas, Universidade Católica de Pelotas/Sociedade Brasileira de Sociologia, pp. 59-75.

SALLUM JR., Brasílio. (2002), “Notas sobre a Gênese da Sociologia Política em São Paulo". Política e Sociedade, vol.1, no 1, pp. 73-86.

SANTOS, Wanderley Guilherme dos. (1978), "Paradigma e História: A Ordem Burguesa na Imaginação Social Brasileira", in Ordem Burguesa e Liberalismo Político. São Paulo, Duas Cidades, pp. 15-63.

SCHERER-WARREN, I. e BENAKOUCHE, Tamara (orgs.). (2002), "Dossiê Sociologia Política. Trajetórias e Perspectivas". Política e Sociedade, vol. 1, no 1, pp. 11-142.

SCHWARZ, Roberto. (1999), "Sobre a 'Formação' da Literatura Brasileira”, in Sequiências Brasileiras: Ensaios. São Paulo, Companhia das Letras, pp. 17-23.

SILVA, Ricardo. (2002), "Sociologia Política e Ideologia Autoritária”. Política e Sociedade, vol. 1, no 1, pp. 103-128.

SKINNER, Quentin. (1999), As Fundações do Pensamento Político Moderno. São Paulo, Companhia das Letras. 
VIANNA, Francisco José de Oliveira. (1973) [1920], Populações Meridionais do Brasil (6a ed.). Rio de Janeiro, Paz e Terra/Governo do Estado do Rio de Janeiro/UFF.

(1991) [1931], “Os Estudos Sociológicos no Brasil”, in Ensaios Inéditos. Campinas, Editora da Unicamp, pp. 89-94.

VILLAS BÔAS, Glaucia. (1992), A Vocação das Ciências Sociais (1945/1964). Um Estudo da sua Produção em Livro. Tese de Doutoramento em Sociologia, Universidade de São Paulo.

(2006), Mudança Provocada. Passado e Futuro no Pensamento Sociológico Brasileiro. Rio de Janeiro, Editora FGV.

WEBER, Max. (1992), "Los Tipos de Dominación", in Economia y Sociedad. México, DF, Fondo de Cultura Económica, pp. 170-241.

WERNECK VIANNA, Luiz. (1993), “Americanistas e Iberistas: A Polêmica de Oliveira Vianna com Tavares Bastos", in E.R. Bastos e J.Q de Moraes (orgs.), O Pensamento de Oliveira Vianna. Campinas, Editora da Unicamp, pp. 351-404.

. (1999), “Weber e a Interpretação do Brasil”, in J. Souza (org.), O Malandro e o Protestante. A Tese Weberiana e a Singularidade Cultural Brasileira. Brasília, Editora da UnB, pp. 173-193. 


\section{ABSTRACT}

Sequences in a Brazilian Political Sociology

By analytically reconstituting how the ideas of Oliveira Vianna were received in research by Victor Nunes Leal, Maria Isaura Pereira de Queiroz, and Maria Sylvia de Carvalho Franco, the article discusses the formation, from the 1920s to the 1970s, of a watershed in Brazilian political sociology oriented towards the investigation of conflict between the private and public orders in the specific configuration of political domination in Brazil.

Key words: Brazilian sociology; public and private; political domination

\section{RÉSUMÉ}

Suites d'une Sociologie Politique Brésilienne

Reprenant analytiquement l'accueil des idées de l'auteur Oliveira Vianna dans des travaux de recherche de Victor Nunes Leal, Maria Isaura Pereira de Queiroz et Maria Sylvia de Carvalho Franco, on examine dans cet article la formation, entre les années 1920 et 1970, d'un courant de la sociologie politique brésilienne orienté vers la recherche du conflit entre les ordres privé et public dans la configuration particulière de la dominance politique au Brésil.

Mots-clé: sociologie brésilienne; public et privé; dominance politique 